
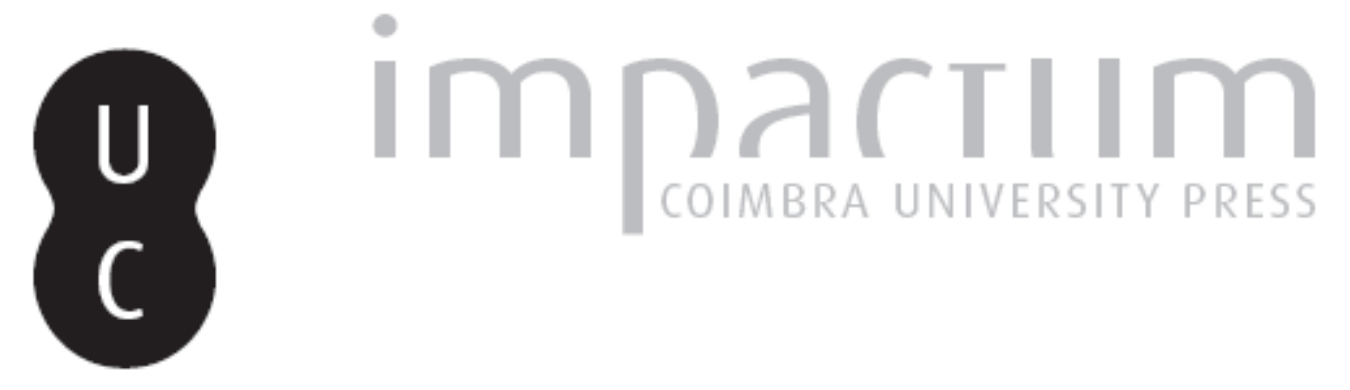

\title{
Design and research in architecture: common points
}

Autor(es): $\quad$ Rodrigues, José Miguel

Publicado por: Editorial do Departamento de Arquitetura

URL persistente:

URI:http://hdl.handle.net/10316.2/37304

DOI:

DOI:http://dx.doi.org/10.14195/1647-8681_4_44

Accessed : $\quad$ 26-Apr-2023 02:40:10

A navegação consulta e descarregamento dos títulos inseridos nas Bibliotecas Digitais UC Digitalis, UC Pombalina e UC Impactum, pressupõem a aceitação plena e sem reservas dos Termos e Condições de Uso destas Bibliotecas Digitais, disponíveis em https://digitalis.uc.pt/pt-pt/termos.

Conforme exposto nos referidos Termos e Condições de Uso, o descarregamento de títulos de acesso restrito requer uma licença válida de autorização devendo o utilizador aceder ao(s) documento(s) a partir de um endereço de IP da instituição detentora da supramencionada licença.

Ao utilizador é apenas permitido o descarregamento para uso pessoal, pelo que o emprego do(s) título(s) descarregado(s) para outro fim, designadamente comercial, carece de autorização do respetivo autor ou editor da obra.

Na medida em que todas as obras da UC Digitalis se encontram protegidas pelo Código do Direito de Autor e Direitos Conexos e demais legislação aplicável, toda a cópia, parcial ou total, deste documento, nos casos em que é legalmente admitida, deverá conter ou fazer-se acompanhar por este aviso.

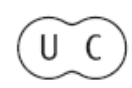




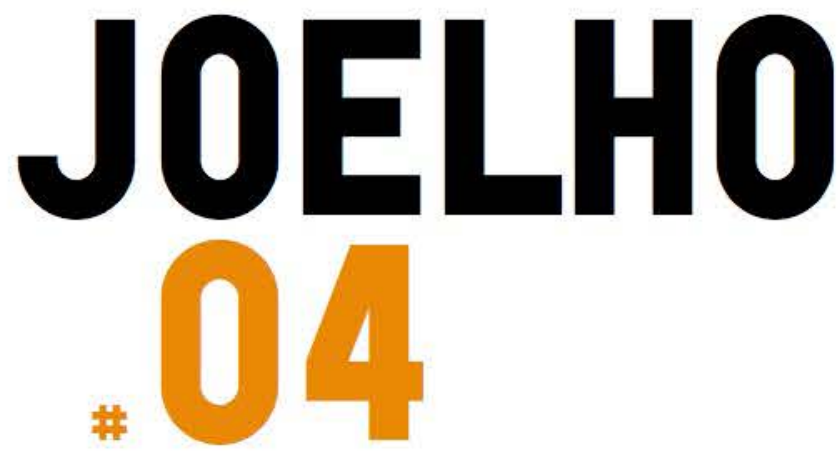

\section{ENSINAR PELO PROJETO \\ TEACHING THROUGH DESIGN}

\section{Coordenaçẫo:}

Paulo Providência

Gonçalo Canto Moniz

Alexandre Alves Costa Juan Domingo Santos Florian Beigel Philip Christou Elizabeth Hatz David Leatherbarrow Andrew Clancy Colm Moore Michael McGarry Willemijn Wilms Floet

Exposição TAPE 20Ir-12 


\section{José Miguel Rodrigues \\ Design and research in architecture: \\ common poinints}

If, at least since the crises of the academic education, teaching architecture through design seems an evidence, yet we can't say the same about the research through design. This modality - which, we should recognize, is still taking the first steps into a world that is strange to it and hostile, even for a lack of knowledge and ignorance - have a history of weight among the treatise History. Think, for instead, in Serlio, but in particular in Palladio, for whom the subject of his "treatise" included - strangely, in the eyes of some, even today! - simultaneously: i.) the ancients, ii.) some contemporary and iii.) their own projects (residing here, perhaps, the most unique aspect of their approach).

One of the main forms of resistance to the research through design has its roots certainly in a methodological dissent that distinguishes architecture from other areas of knowledge: its natural and unrestrained vocation to action that often leads the charge of moralism, not by chance. In this sense, the architectural thought differs from other forms of thoughts that don't depend on the action as a link of its intelligibility.

The question, however, is not peaceful even within the discipline, emerging - inclusive - from its theoretico-practical sectors, ie., in the authors with written and design activity, definitely most established and known by the theoretical dimension of their work, than the practical one. When despite the warnings of Ignasi Solà-Morales (2003, p.257-266), Maurici Pla argues that the rise of a logos written (specifically disciplinary) shows "that one thing is to write and the other is to design and is as absurd to design with words, as to write with architectural materials" (Pla, 2006, p.11, 12) this issue is what, precisely, reappears.

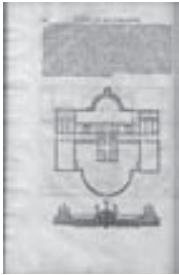

1. Andrea Palladio, Villa Barbaro, Maser, Treviso (1549/1551-1558).

(André Palladio, Les quatre livres de $l^{\prime}$ architecture d'André Palladio. Paris, [s.n.] 1650, p.120).

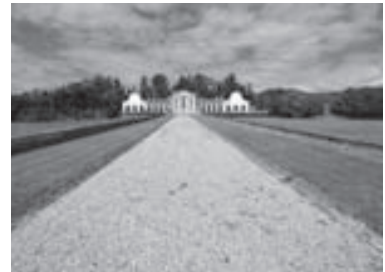

2. Andrea Palladio, Villa Barbaro, Maser, Treviso (1549/1551-1558). (Cortesia de Manuel Montenegro).

Although always precariously, to enjoy the debate of philosophers concerning the knowledge and its methods, may reveal useful to the architect-researcher. If to the random investigation and to the strictly rational investigation we can counteract, in the general area of thought, the heuristics - while tentative method based on experience - why not, also, accept and develop a research in architecture based and supported in the design processes? What is the difference between the search for alternatives in a succession of sheets of tracing paper (where the experience lies in the very chain of overlapping possible solutions to the same problem of design) and the heuristics that, as Fernando Gil refers, aims to "dramatically reduce the space of the possibilities of analysis, setting preferred way to solve problems (...)" (Gil, 1984, p.266)? What is the disagreement between the heuristic "where the "intuition" is absolutely decisive" and the design in a studio of architecture? How to face, to gauge and measure, in this perspective, the gains of the knowledge in the disciplinary area of architecture if, as also Fernando Gil refers, "the heuristics are already discovers" concerning to individual inventiveness "uncover the best way to get the adequate information" and "to organize the final results from fragmentary elements"? (Gil, 1984, p.274-275)

If the positive response to the reasoning of the above questions can even gather a certain consensus - ie., if the methodological sharing of architectural research in an academic environment and of project activity in an atelier environment seems indispensable - yet the contamination between the two activities seems also to cause a lot of resistance and even some distrust. The truth is that this second

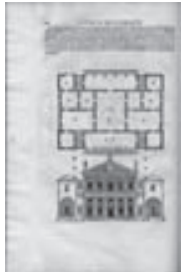

3. Andrea Palladio, Villa Valmarana Zen, Vicenza (1570).

(André Palladio, Les quatre livres de I' architecture d'André Palladio. Paris, [s.n.] 1650, p.128).

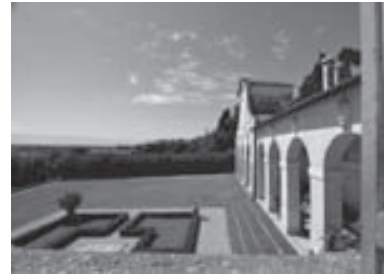

4. Andrea Palladio, Villa Barbaro, Maser, Treviso (1549/1551-1558). (Cortesia de Manuel Montenegro). 
resistance seems more insurmountable (the first - remember concerned the sharing of methods, while the second refers the sharing of the object of study and research purpose). And, in this sense, the reflection on its causes, but also the many examples with success of the opposite, cannot ignore our attention.

Largely, as well explained Ignasi de Solà-Morales (2003, p.157-166), the resistance to the research in project and through the project, is explained by the divorce between theory and practice that both exclusionary sectors of the discipline cultivated for reasons of self-defense that only theoretical-practical architects (from my perspective, as Rafael Moneo and Giorgio Grassi, to give two examples sufficiently known) were prepared to dismantle and undermine. Ie., only in this divided position - between the project as action and the project as an occasion for reflection - is possible to realize that the concatenation of these two dimensions of the discipline is what precisely allows raising, at the highest level (including of demand) the architectural research. Without action, "the architectural research runs the risk of becoming an in-vitro activity" - as well noticed Ignasi de Solà-Morales (2003, p.265).

Note, for example, the Four Books of Palladio (a text written in the mature phase of the author) and the projects that this architect was keen to publish in his treatise. See as, in it, projects (built or not, is irrelevant) and thinking are the two sides of the same coin, who, precisely because of that, and despite the inconsistencies (or even more, certainly also because of those inconsistencies), they clarify each other. Imagine reading the Palladian considerations contained in his treatise, without his design projects that in part even contradicts them. The degree of impoverishment of knowledge that we would have about this author today, would be immeasurable. Indeed, some might say, that Alberti did not need, at least apparently, this feature (ie, the simultaneous presence, in his treatise, of the architecture that he designed and built and his architectural ideas). It is also true that an author like Giorgio Grassi, is able to write very important pages about Alberti, without ever referring to his works, to indirectly talk about his own architecture. But the truth is that their works exist and is their existence - even material and concrete - that allows us, as indeed in Alberti, to read their texts in a theoretical and practical perspective - what, precisely, we lack in a writer as Vitruvius (for continuing to exemplify based on treatises). On the other hand, it is enough to think on the interest expressed and developed, over the centuries, for the unique architectural work that can be attributed with certainty to this author - The Basilica of Fano that remains a mystery until today - for, without much effort, then be able to estimate the relevance of this "failure" in understanding the Vitruvian thought, thus totally dependent on the difficult and fragile exegesis of his text, in confrontation with his only known building, by misfortune undocumented and obliterated by time.

But if the question arises in the dissension between theory and practice, how the debate of philosophers will continue to remain useful? Remind, in clarifying this doubt, the distinction between theoretical problems and practical problems that Ortega e Gasset provides:
Let us try to define the mental attitude where appears a practical problem. (...) Suddenly we feel something forced or a wish that, to satisfy itself, required a surrounding reality different from that is: a stone, for example, prevents that we move forward along the way. The practical problem consist of having a path without stone - so, something that it is not, comes to be. The practical problem is a mental attitude in which we design a modification of the real, where we premeditate to give being to what is not yet, but we ought to be.

(Gasset, 1995, p.61)

Nothing more diverse in this attitude than that when a theoretical problem arises. The expression of the problem in the language is the question: 'What is such or that thing?' Notice what has of special this mental fact, of equal search. What we ask ourselves: 'What is it? It is there, it is - in either direction - otherwise, would not occur to us to ask ourselves something about it. But it happens that we are not satisfied with what it is and be there - but, on the contrary, it restless us that it is and that it is just as it is, irritates us its being. Why? Obviously because that which is, as it is before us, it is not enough to itself, but rather, we see that it lacks its reason of being. (...) It follows that there is no theoretical problem if we not begin from something that is, that is undeniably there, and despite of this or because of that, is thought as not being, as it shouldn't be. The theory - it should be emphasized the extravagance of the fact - begins, therefore, by denying reality, violently destroying the world, annihilating it; (...) If, so, the practical problem consists in doing to be what it is not - but should - the theoretical problem consist in doing not to be what is - but because it is such it irritates the intellect with its insufficiency.

(Gasset, 1995, p.61, 62)

Who read these words cannot be indifferent to the two described lines of action. From the perspective of the practical problem: I.) the desire (or the drawing) of a reality different from what it is; II.) that something that is not comes to be, III.) the mental attitude, implied; IV.) the premeditations to give existence to what is not yet; and v.) the desirability of what we ought to be. Already in the perspective of the theoretical problem: I.) the expression of the problem through a question; II.) the not satisfying with it being there, III.) on the contrary, the disquiet us, IV.) to see that is lacking its reason of being, V.) the need to destroy the world as it is, needed to face the theoretical problem.

However, this inability to remain indifferent to both procedures, means nothing but the multiple interest for these two lines of action that, in a compound word (so, naturally imperfect), gather at the idea of putting the theoretical-practical research in architecture. That is, a perspective in which, to design what can and we desire to be and to study what exists, is there and already is, are paths that, just concomitantly, enhance a research specifically in architecture.

\section{Bibliographical References}

Gil, F. (1984). Mimésis e Negação. Lisboa: INCM.

Ortega Y Gasset, J. (1995) O que é a Filosofia? Curso em 11 lições seguido de Porque se volta à filosofia? Lisboa: Cotovia [1957].
Palladio, A. (1965) The Four Books of Architecture, (int. Adolf K. Placzeck). New York: Dover Publications [ $1^{\text {a }}$ ed. 1570$]$.

$\mathrm{Pla}, \mathrm{M}$. (2006). La Arquitectura a través del lenguaje, escritos 1989-2002. Barcelona: Gustavo Gili.
Solà-Morales, I. (2003). Inscripciones. Barcelona: Editorial Gustavo Gili. 